\title{
Clinical and epidemiological aspects of canine parvovirus (CPV) enteritis in the State of Rio de Janeiro: 1995 - 2004
}

\author{
[Aspectos clínicos e epidemiológicos da enterite por parvovírus canino (CPV) no estado do \\ Rio de Janeiro: 1995-2004] \\ T.X. Castro ${ }^{1}$, S.C. Miranda ${ }^{1}$, N.V.Labarthe ${ }^{2}$, L.E. Silva ${ }^{3}$, R.C.N. Cubel Garcia ${ }^{1 *}$ \\ ${ }^{1}$ Departamento de Microbiologia e Parasitologia - UFF \\ Rua Prof. Hernani Melo 101 \\ 24210-130 - Niterói, RJ \\ ${ }^{2}$ Faculdade de Veterinária - UFF - Niterói, RJ \\ ${ }^{3}$ Instituto de Matemática - UFF - Niterói, RJ
}

\begin{abstract}
This paper relates the clinical and epidemiological aspects of canine parvovirus infection (CPV) in the State of Rio de Janeiro from April 1995 to March 2004. A total of 341 fecal samples were collected from up to 6-months-old puppies with gastroenteritis. The diagnosis of CPV infection was confirmed by hemagglutination/ hemagglutination inhibition tests, enzyme immunoassay, virus isolation in cell culture or polymerase chain reaction. One hundred and fifty-seven samples $(46 \%)$ were positive for CPV. No correlation among sex, breed or age and the occurrence of CPV infection was observed. The classical signs of parvoviral enteritis (anorexia, lethargy, vomiting and hemorrhagic fluid diarrhea) were observed in $70 \%$ of CPV-positive and in $60 \%$ of CPV-negative puppies. Although CPV could be detected throughout the studied period, its occurrence was significantly higher from June to September and November to December. These results show that CPV is still circulating in the State of Rio de Janeiro.
\end{abstract}

Keywords: canine parvovirus (CPV), Rio de Janeiro, clinical signs, enteritis

\section{RESUMO}

Este trabalho relata os aspectos clínicos e epidemiológicos da infecção pelo CPV no Estado do Rio de Janeiro, no periodo de abril de 1995 a março de 2004. Coletaram-se 341 amostras fecais de cães com até seis meses de idade que apresentavam gastrenterite. O diagnóstico da infecção pelo CPV foi confirmado através dos testes de hemaglutinação/inibição da hemaglutinação, ensaio imunoenzimático, isolamento viral em cultura de células ou reação em cadeia pela polimerase. Cento e cinqüenta e sete amostras (46\%) foram consideradas positivas para CPV. Não foi observada correlação entre sexo, raça ou idade e a ocorrência da infecção por CPV. Os sinais clinicos clássicos de parvovirose (vômito, anorexia, apatia e diarréia líquida hemorrágica) foram observados em $70 \%$ dos animais positivos e $60 \%$ dos animais negativos para CPV. O CPV foi detectado ao longo do periodo estudado, entretanto observou-se um aumento do número de casos positivos nos periodos de junho a setembro e novembro a dezembro. Estes resultados mostram que o CPV ainda circula no Estado do Rio de Janeiro.

Palavras-chave: parvovírus canino (CPV), Rio de Janeiro, sinais clínicos, enterite

Recebido em 5 de setembro de 2006

Aceito em 12 de fevereiro de 2007

*corresponding author (autor para correspondência)

E-mail: ritamip@vm.uff.br

Apoio: $\mathrm{CNPq}$ 


\section{INTRODUCTION}

Since the emergence of canine parvovirus (CPV) in the late 1970s, virus enteritis has become recognized as one of the most common causes of infectious diarrhea in puppies (Pollock and Coyne, 1993). Although parvovirus infection can be controlled by vaccination, several reports show CPV infection in puppies to be a significant cause of morbidity in Brazil (Homem et al., 1999; Cubel Garcia et al., 2000, 2002).

After the appearance of CPV (CPV-2), analyses of isolates revealed the emergence of new antigenic types termed CPV-2a and CPV-2b in 1979 and 1984, respectively. These variants can be distinguished from the original CPV-2 by using monoclonal antibodies, restriction enzymes and more recently by polymerase chain reaction (PCR). Several reports show that the original CPV-2 is no longer circulating while the new variants $\mathrm{CPV}-2 \mathrm{a}$ and $\mathrm{CPV}-2 \mathrm{~b}$ are variously distributed in canine populations worldwide, with no difference in the pathogenesis (Parrish et al., 1985, 1988; Mochizuki et al., 1993; Senda et al., 1995; Pereira et al., 2000; Costa et al., 2005).

The clinical manifestation of CPV infection depends on the age and immune status of the animal, the virulence of the virus, the dose of infectious virus and the preexisting or concurrent parasitic, bacterial or virus infections (McAdaragh et al., 1982; Hagiwara et al., 1996). It has also been reported that Doberman Pinscher, Rottweiler and German Shepherd dogs appear to be under greater risk of developing parvoviral enteritis (Glickman et al., 1985; Houston et al., 1996).

In puppies, the prodromal signs such as lethargy, anorexia and fever appear 4-5 days after infection (PI), followed by an acute onset of vomiting and hemorrhagic diarrhea (5-6 days PI). Viral particles in fecal samples of infected dogs can be detected by hemagglutination test from 3 to 9 days after oral infection and the maximum viral shedding occurs between days 57 PI (Carmichael et al., 1980; Studdert et al., 1983; Macartney et al., 1884). For laboratory testing, the fecal samples should be collected as soon as the enteric signs appear (Carmichael et al., 1980; McAdaragh et al., 1982; Macartney et al., 1984).
Several diagnostic tests have been used to detect the virus or the virus genome in fecal samples of dogs with gastroenteritis: hemagglutination (HA) followed by hemagglutination-inhibition (HI) test, enzyme immunoassay (EIA), virus isolation in cell culture and polymerase chain reaction (PCR) (Carmichael et al. 1980; Senda et al., 1986; Mochizuki et al., 1993; Senda et al., 1995; Pereira et al., 2000; Costa et al., 2005). PCR has been mostly used for genomic typing of circulating parvovirus strains (CPV-2a or CPVb) as well as to confirm the presence of wild virus $(\mathrm{CPV}-2 \mathrm{a} / 2 \mathrm{~b})$ in fecal samples of puppies that had received CPV-2 (old type) live virus vaccine (Mochizuki et al., 1993; Senda et al., 1995; Pereira et al., 2000; Costa et al., 2005). This confirmation is particularly important for those animals presenting clinical signs during the period of vaccine virus shedding (3-9 days posvaccination) (Carmichael et al., 1981; Costa et al., 2005).

The purpose of this study was to evaluate CPV infection in puppies with gastroenteritis up to 6months-old. In addition, it was performed an update of the clinical signs and predisposing factors (sex, breed, age, and seasonality) of parvoviral enteritis in the State of Rio de Janeiro, Southwestern Brazil.

\section{MATERIALS AND METHODS}

A total of 341 fecal samples, collected during the years 1995-2004 from up to 6-month-old puppies with diarrhea were obtained from different sources within a range of $55 \mathrm{~km}$ from the Meteorology Laboratory at the Universidade Federal Fluminense situated at S22 ${ }^{\circ} 53.806^{\prime}$ W043 $3^{\circ} 07.774$ '. The greater part of these samples (274) were collected by clinicians from a) the Policlínica Veterinária, Universidade Federal Fluminense, Niterói (179) and b) private animal hospitals (95) in the cities of Niterói (34), Rio de Janeiro (30), Teresópolis (23), Petrópolis (6), São Gonçalo (1) and Nova Iguaçu (1). Another 67 samples were collected by our group in the city of Rio de Janeiro: 19 in an animal shelter, 35 in the public animal hospital, Instituto Municipal de Medicina Veterinária Jorge Vaitsman, and 13 from a private veterinary office.

With consent of the owners of the animals, fecal samples were collected after spontaneous 
intestinal discharge. All the used samples were stored at $-20^{\circ} \mathrm{C}$ prior to examination. Information regarding sex, breed, age, days of disease, clinical findings and CPV vaccination history was drawn from the records.

One hundred and thirty-seven samples were collected from mixed-breed puppies and 201 from purebred puppies: Poodle Toy (37), German Shepherd (35), Rottweiler (21), Cocker Spaniel (19), Fila Brasileiro (13), American Pit Bull Terrier (10), Siberian Husky (9), Doberman Pinscher (8), Labrador Retriever (7) and Yorkshire Terrier (6), Boxer (5), Teckel (5), Great Dane (5), Pinscher (4), Golden Retriever (2), Shar-pei (2), Terrier Brasileiro (2), Akita (1), Basenji (1), Basset Hound (1), Beagle (1), Bull Terrier (1), Collie (1), Dalmatian (1), Pekingese (1), Irish Setter (1), Staffordshire Terrier (1) and Weimaraner (1). For three puppies, no breed information was available.

Approximately $10 \%$ suspensions from all fecal samples (341) were prepared in Hank's balanced salt solution or Tris- $\mathrm{Ca}^{2+}(0.01 \mathrm{M}, \mathrm{pH}$ 7.2) (Carmichael et al., 1980; Costa et al., 2005). The $10 \%$ suspensions were then tested for the presence of CPV by hemagglutination test (HA) with porcine or rhesus monkey erythrocytes and confirmed as positive by hemagglutinationinhibiton (HI) test (Cubel Garcia et al., 2000). One hundred and twenty-five samples were used in the testing.

A total of 216 samples was tested by another method in order to confirm CPV diagnosis: virus isolation in cell culture Madin-Darby Canine Kidney - MDCK, commercially available enzyme immunoassay ${ }^{1}$ and the polymerase chain reaction (PCR) (Cubel Garcia et al., 2002; Costa et al., 2005). All the HA/HI positive samples from vaccinated puppies were submitted to PCR with differential primers in an attempt to distinguish wild from modified-live vaccine virus (Costa et al., 2005).

The monthly temperature and relative humidity means from April 1998 to March 2004 were obtained from the Meteorology Laboratory at the Universidade Federal Fluminense.

The statistical significance of proportions (sex, temperature, vaccination and season) was

\footnotetext{
${ }^{1}$ Idexx Laboratories Inc.- West brook, USA
}

examined by Z-test and a probability less than 0.05 was regarded significant. The significance (at $\mathrm{P}<0.05$ ) of association between two categorical variables (CPV enteritis and age/breed/clinical signs of puppies) was determined by Chi-square test $\left(\chi^{2}\right)$.

\section{RESULTS}

Fecal samples from 180 male and 158 female puppies with gastroenteritis were tested. Fortysix percent from these (157/341) were positive (78 male and 78 female). For three puppies, one positive for CPV, sex data were not recorded. No statistical difference in relation to sex was found (Table 1).

Approximately $50 \%$ of mixed-breed puppies $(67 / 137)$ and $44 \%$ of purebred puppies $(89 / 201)$ were CPV positive, showing no statistically significant difference between these breed categories $(\mathrm{P}>0.05)$. As shown in Table 1, 31.8\% of purebred puppies (64/201) were from susceptible breeds: German Shepherd, Rottweiler and Doberman Pinscher.

According to the information provided by the owners of the puppies, $81 \%$ of the samples $(275 / 341)$ were collected within one (42 samples), two (95), three (92) or four (46) days after the onset of the clinical signs. One hundred and thirty-four $(85 \%)$ of these samples were positive. The major part of the samples (258/341) was from 2 to 4-month-old puppies and the proportion of CPV positive samples in this group was higher than in the puppies of other ages $(\mathrm{P}<0.05)$.

The classical clinical signs of CPV enteritis (vomiting, anorexia, lethargy and hemorrhagic fluid diarrhea) could be observed in 69\% (109/157) of the CPV positive and $60 \%(111 / 184)$ of CPV negative puppies. For the remaining 121 puppies, the association of clinical signs was variable (Fig. 1). The comparison of the clinical signs observed in CPV-positive and CPV-negative puppies showed no difference $(\mathrm{P}>0.05)$.

The classical clinical signs of CPV enteritis were observed in $75 \%(21 / 28)$ of the CPV-positive puppies from susceptible breeds and in $66 \%$ $(85 / 128)$ of all the other puppies (purebred and mixed-breed). This difference however was not statistically significant $(\mathrm{P}>0.05)$. 
Table 1. Number of samples from puppies up to 6-month-age tested for CPV infection according to sex, breed-susceptibility and vaccination.

\begin{tabular}{|c|c|c|c|c|}
\hline & \multicolumn{2}{|l|}{ Samples } & \multicolumn{2}{|c|}{ Statistical analysis } \\
\hline & positive / total & $(\%)$ & $\mathrm{Z}$ & $\mathrm{P}^{\mathrm{a}}$ \\
\hline \multicolumn{5}{|l|}{ Sex } \\
\hline $\begin{array}{l}\text { Male } \\
\text { Female }\end{array}$ & $\begin{array}{l}78 / 180 \\
78 / 158\end{array}$ & $\begin{array}{l}(43.3) \\
(49.4)\end{array}$ & 1.11 & 0.267 \\
\hline \multicolumn{5}{|l|}{ Breed } \\
\hline $\begin{array}{l}\text { susceptible }^{\mathrm{b}} \\
\text { non susceptible }\end{array}$ & $\begin{array}{l}28 / 64 \\
129 / 277\end{array}$ & $\begin{array}{l}(43.8) \\
(46.6)\end{array}$ & 0.41 & 0.683 \\
\hline \multicolumn{5}{|l|}{ Vaccinated } \\
\hline $\begin{array}{l}\text { yes } \\
\text { no }\end{array}$ & $\begin{array}{l}46 / 96 \\
97 / 213\end{array}$ & $\begin{array}{l}(47.9) \\
(45.5)\end{array}$ & 0.36 & 0.716 \\
\hline
\end{tabular}

${ }^{\mathrm{a}} \mathrm{P}<0.05$ significant

${ }^{\mathrm{b}}$ German Shepherd (14/35), Rottweiler (10/21) and Doberman Pinscher (4/8)

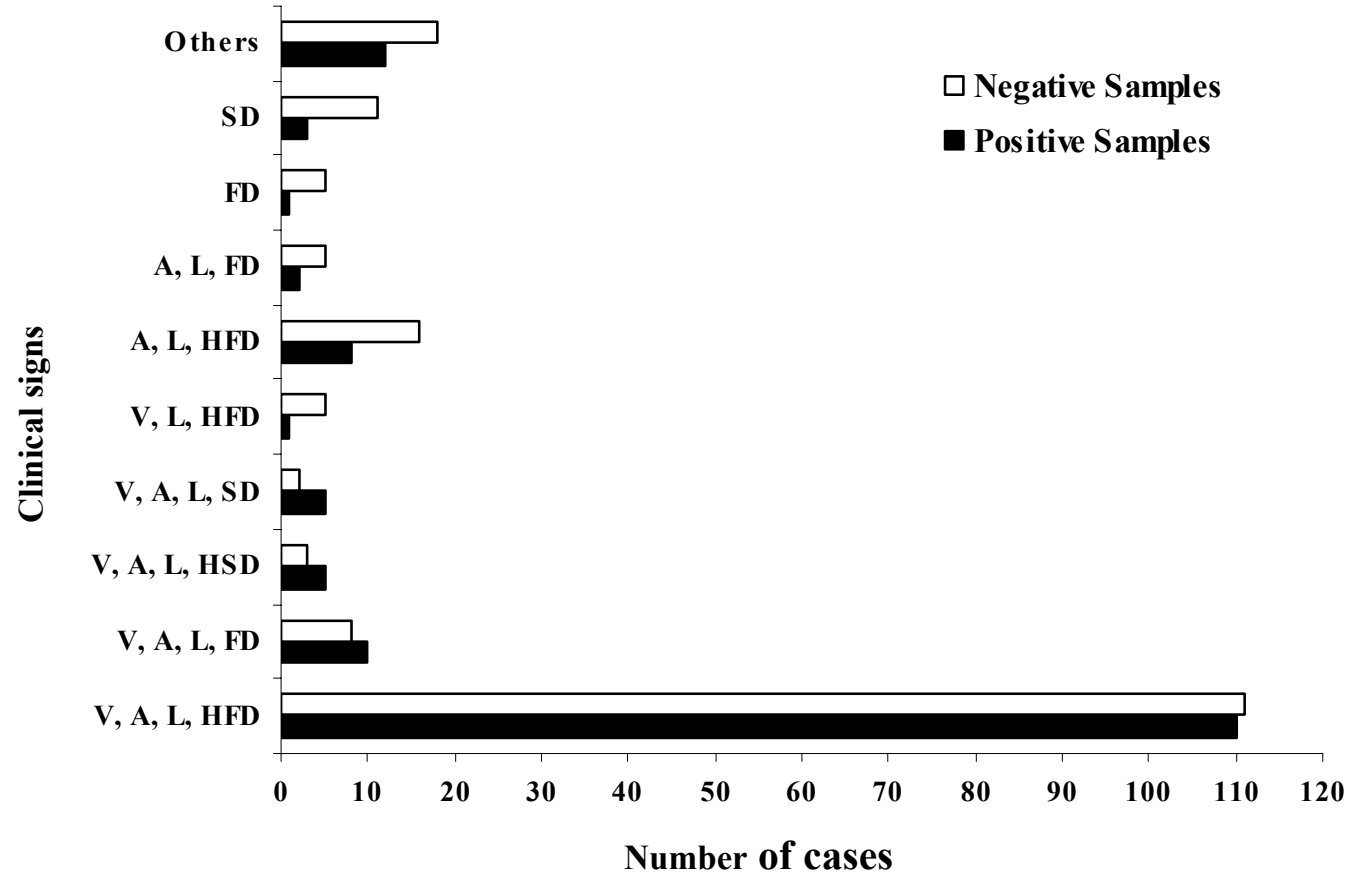

Figure 1. Clinical signs of 341 puppies with gastroenteritis up to 6-moth-age with and without CPV infection. V: vomiting; A: anorexia; L: lethargy; F: fluid; S: soft; H: hemorrhagic; D: diarrhea.

Others: CPV positive: V, A, HFD (1); V, A, HSD (1); V, L, HSD (1); V, FD (1); V,SD (1); A, L, HSD (1); A, L, SD (1); A, HFD (1); A, HSD (1); L, HFD (1); L, SD (1). CPV negative: V, A, HFD (2); V, A, FD (1); V, L, HSD (2); V, L, SD (1); V, FD (2); A, L, HSD (1); A, L, SD (2); A, FD (2); A, SD (1); L, HFD (1); L, SD (2) HSD (1).

Hyperthermia $\left(>39.5^{\circ} \mathrm{C}\right)$ was observed in both CPV infected (24/115) and non-infected (30/127) puppies. For 99 puppies these data was missed in the records. No statistical difference with regard to hyperthermia and CPV infection was found $(\mathrm{P}>0.05)$.
Vaccinated puppies $(46 / 96-47.9 \%)$ as well as non-vaccinated puppies $(97 / 213$ - 45.5\%) were infected (Table 1). From 32 puppies for which vaccination data were missed, 14 (44\%) were infected. 
For 34 out of the $46 \mathrm{CPV}$ positive vaccinated puppies, the interval between vaccination and the onset of the clinical signs was known and, from these, 13 samples were collected during the period of vaccine virus shedding (3-9 days postvaccination). As these 13 puppies were vaccinated with old type virus (CPV-2), PCR could confirm the infection with wild virus (CPV-2b). For 12 at of the 46 vaccinated puppies vaccine data were missed.
The proportion of positive cases and the monthly temperature and relative humidity means for the period from April 1998 to March 2004 were analyzed (Fig. 2). Although parvovirus could be detected throughout the studied period, a significant raise $(\mathrm{P}<0.05)$ in the occurrence of CPV from June to September and from November to December was observed.
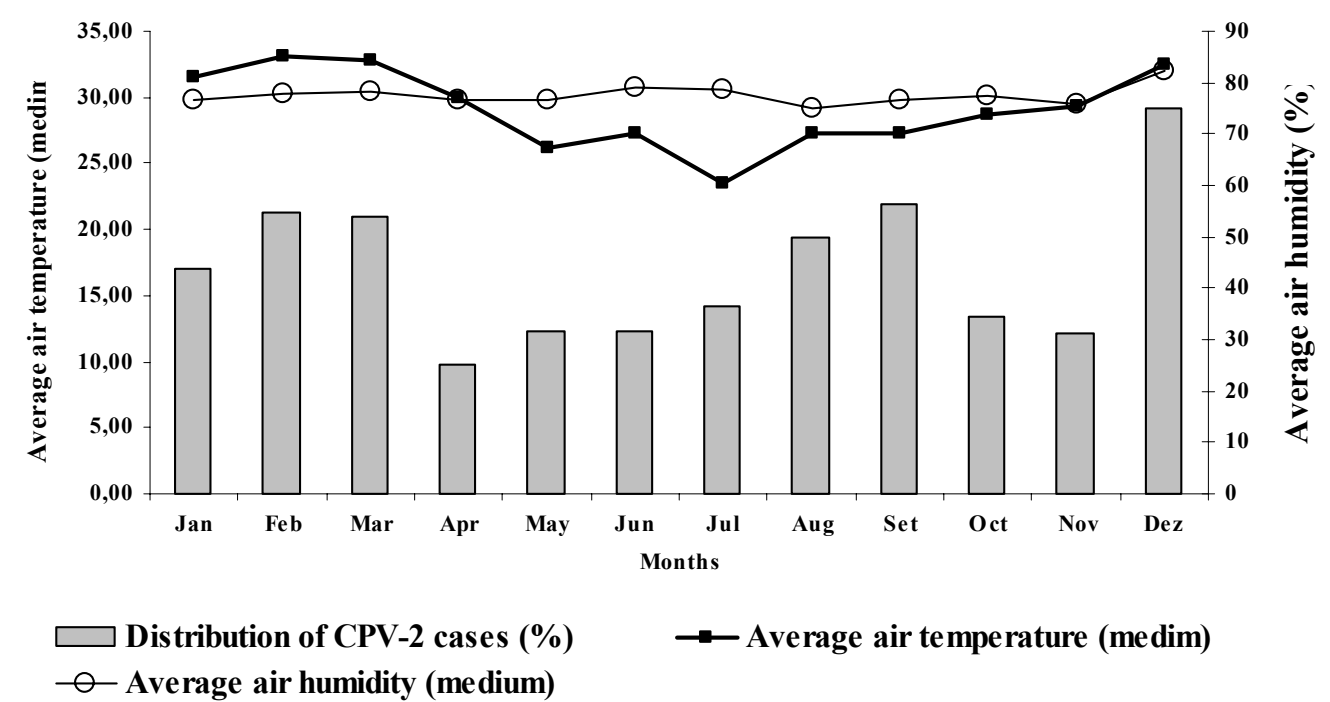

Figure 2. Correlation between the distribution of CPV cases and the monthly average temperature and relative humidity from 1998 to 2004 (Metereology Laboratory - Universidade Federal Fluminense).

\section{DISCUSSION}

It was possible to demonstrate canine parvovirus infection in $46 \%$ of the puppies with gastroenteritis from April 1995 to March 2004. Though $80 \%$ of the analyzed samples were collected during maximum virus shedding ( 1 to 4 days PI) when it is possible to detect the virus using HA assay (Carmichael et al., 1980; Studdert et al., 1983), the major part of the samples were also tested by another method (virus isolation in cell culture, enzyme immunoassay or PCR) in order to improve accuracy.

No association of CPV enteritis with the sex of the dogs was found. This is in agreement with other reports that also showed the risk of infection not to be significantly higher for males than for females (Glickman et al., 1985; Houston et al., 1996)

As also demonstrated by other authors (Houston et al., 1996; Homem et al., 1999), in this study, most of the diarrheic samples were obtained from 2-4 month-old puppies. It is well known that increased intestinal epithelial turnover caused by changes in the bacterial microbiota and diet (weaning) is a predisposing factor to CPV infection (McAdaragh et al., 1982; Hagiwara et al., 1996).

In this survey, the classical signs of CPV infection were identified in $70 \%$ of CPV-positive 
and $60 \%$ of CPV-negative puppies, suggesting that the clinicians, aware of the objective of this study, probably collected samples based on this criterion. As also suggested by other authors, hyperthermia $\left(>39.5^{\circ} \mathrm{C}\right.$ ) should not be correlated to parvoviral enteritis (Hagiwara et al., 1980; McAdaragh et al., 1982) since no association with the disease could be established.

It has further been reported that Doberman Pinscher, Rottweiler and German Shepherd puppies are under greater risk of developing CPV enteritis than mixed-breed dogs. The reasons for this are unknown. These breeds may be more susceptible to infection or develop more severe disease when infected (Glickman et al., 1985; Houston et al., 1996). In this study, approximately $50 \%$ of the purebred puppies were from susceptible breeds and the greater part of them $(75 \%)$ presented the classic clinical signs, associated with severe disease. The great variety of breeds used in this study, however, made it difficult to associate an increased risk for developing CPV enteritis with any specific breed.

Parvoviral enteritis can be controlled by vaccination but it is well known that maternally derived antibodies may interfere with the immune response of the puppies. In order to achieve appropriate protection, it is necessary to complete the vaccination schedule (Pollock and Coyne, 1993). The comparison of vaccinated and non-vaccinated CPV-positive puppies in this study may lead to an erroneous interpretation of the importance of vaccination for the prevention of the disease. It must be pointed out that $43 / 46$ vaccinated puppies had not completed the vaccination schedule.

$\mathrm{HA} / \mathrm{HI}$ tests for virus diagnosis do not allow distinguishing between wild or vaccine virus (Mochizuki et al., 1993; Senda et al., 1995; Pereira et al., 2000). The samples collected from vaccinated puppies during the period of vaccine virus shedding were submitted to PCR with differential primers and PCR could confirm the presence of wild virus (CPV-2b) since these puppies had received CPV-2 (old type) live virus vaccine. As most of the vaccines marketed in Brazil for parvovirus prevention are CPV oldtype, PCR can be a useful tool for elucidating CPV infection in vaccinated puppies (Costa et al., 2005).
One of the trends noted in this study was that seasonal variation did not seem to interfere with the circulation of CPV although an increase of CPV positive cases from June to September and from November to December could be observed. While data published by Stann et al. (1984) seem to support this finding, others found seasonal bases for the occurrence of CPV infection (Houston et al., 1996; Mason et al., 1987).

These results show that CPV is circulating in the State of Rio de Janeiro and that laboratory diagnosis of canine parvovirus infection should be included in the differential diagnosis of enteric diseases, especially for puppies up to 6month-old.

\section{ACKNOWLEDGEMENTS}

We thank the clinicians from Policlínica Veterinária/UFF and other private animal hospitals, a public shelter and the Animal Hospital - Instituto Municipal de Medicina Veterinária Jorge Vaitsman - for supplying the fecal samples. The authors also thank Prof. Evandro Barbieri, Instituto de Geoquímica/UFF, who kindly provided the meteorological data, Idexx Laboratory Inc., as well Dr. Liliane M. V. Willi, Universidade Castelo Branco and Dr. José Paulo G. Leite, Fundação Oswaldo Cruz for their cooperation. The authors also wish to thank Christiane Pflegshorl for critical reading of the manuscript. T.X. Castro was awarded with a graduate fellowship from CAPES for participating in the MSc Program of the Faculdade de Medicina Veterinária - UFF.

\section{REFERENCES}

CARMICHAEL, L.E.; JOUBERT, J.C.; POLLOCK, R.V. Hemagglutination by canine parvovirus: serologic studies and diagnostic applications. Am. J. Vet. Res., v.41, p.784-791, 1980.

CARMICHAEL, L.E.; JOUBERT, J.C.; POLLOCK, R.V. A modified live canine parvovirus strain with novel plaque characteristics I: viral attenuation and dog response. Cornell Vet., v.71, p.784-791, 1981.

COSTA, A.P.; LEITE, J.P.; LABARTHE, N.V. et al. Genomic typing of canine parvovirus circulating in the State of Rio de Janeiro, Brazil 
from 1995 to 2001 using polymerase chain reaction assay. Vet. Res. Commun., v.29, p.735743,2005

CUBEL GARCIA, R.C.N.; PINTO, A.; COSTA, A.; MACIEL, B. et al. Canine parvovirus infection in puppies with gastroenteritis in Niterói, Rio de Janeiro, from 1995 to 1997. Braz. J. Vet. Res. Anim. Sci., v.37, p.132-135, 2000.

CUBEL GARCIA, R.C.N.; LEITE, J.P.; XAVIER, M.P.T. et al. Infecção pelo parvovírus canino no Rio de Janeiro: Um Estudo de 5 anos. Rev. Bras. Cienc. Vet., v.9, p.42-46, 2002.

GLICKMAN, L.T.; DOMANSKI, L.M.; PATRONEK, F.J. et al. Breed-related risk factors for canine parvovirus enteritis. J. Am. Vet. Med. Assoc., v. 187, p.589-594, 1985.

HAGIWARA, M.K.; JULY, J.R.; BACCARO, M.R. et al. Enterite hemorrágica em cães associada à infecção por um Parvovírus. Arq. Inst. Biol., v.47, p.47-49, 1980.

HAGIWARA, M.K., MAMIZUKA, E.M., PAVAN, M.F. Role of intestinal flora in acute hemorrhagic gastroenteritis (Parvovirus infection) of dogs. Braz. J. Vet. Res. Anim. Sci., v.33, p.107-109, 1996

HOMEM, V.S.F.; MENDES ,Y.G.; LINHARES, A .C. Gastroenterite canina- agentes virais nas fezes de cães diarreicos e não diarreicos. Arq. Bras. Med. Vet. Zootec., v.51, p.531-536, 1999.

HOUSTON, D.M.; RIBBLE, C.S.; HEAD, L.L. Risk factors associated with parvovirus enteritis in dogs: 283 cases (1982-1991). J. Am. Vet. Med. Assoc., v.208, p.542-546, 1996.

MACARTNEY, L.; McCANDLISH, I. A.; THOMPSON, H. et al. Canine parvovirus enteritis 1: Clinical, haematological and pathological features of experimental infection. Vet. Rec., v.115, p.201-210, 1984.

MASON, M.J.; GILLETT, N.A.; MUGGENBURG, B.A. Clinical, pathological, and epidemiological aspects of canine parvoviral enteritis in an unvaccinated closed beagle colony: 1978-1985. J. Am. Anim. Hosp. Assoc., v.23, p.183-192, 1987.
McADARAGH, P; EUSTIS, S.L.; NELSON, D.T. et al. Experimental infection of conventional dogs with canine parvovirus. Am. J. Vet. Res., v.43, p.693-696, 1982.

MOCHIZUKI, M.; SAN GABRIEL, M.C.; NAKATANI, $H$. et al. Comparison of polymerase chain reaction with virus isolation and haemagglutination assays for the detection of canine parvoviruses in faecal specimens. Res. Vet. Sci., v.55, p.60-63, 1993.

PARRISH, C.R., O'CONNELL, P.H., EVERMANN, J.F. et al. Nature variation of canine parvovirus. Science, v.230, p.1046-1048, 1985.

PARRISH, C.R., HAVE, P.D., FOREYT, W.J. et al. The global spread and replacement of canine parvovirus strains. J. Gen. Virol., v.69, p.11111116, 1988.

PEREIRA, C.R.; MONESI, T.A.; MENHERT, D.U. et al. Molecular characterization of canine parvovirus in Brazil by polymerase chain reaction assay. Vet. Microbiol., v.75, p.127-133, 2000.

POLLOCK, R.V.H.; COYNE, M.J. Gastroenterology: Canine Parvovirus. Vet. Clin. North Am. Small Anim. Pract., v.23, p.555-569, 1993.

SENDA,M.; HIRAYAMA, N.; YAMAMOTO, $\mathrm{H}$. et al. An improved hemagglutination test for study of canine parvovirus. Vet. Microbiol., v.12, p.1-6, 1986.

SENDA, M.; PARRISH, C.R.; HARASAWA, R. et al. Detection by PCR of wild-type canine parvovirus which contaminates dog vaccines. $J$. Clin. Microbiol., v.3, p.110-113, 1995.

STANN, S.E.; DIGIACOMO, R.F.; GIDDENS, W.E. Clinical and pathologic features of parvoviral diarrhea in pound-source dogs. J. Am. Vet. Med. Assoc., v.185, p.651-655, 1984.

STUDDERT, M.J.; ODA, C.; RIEGL, C.A. et al. Aspects of the diagnosis, pathogenesis and epidemiology of canine parvovirus. Aust. Vet. J., v.60, p.197-, 1983 